\title{
Precision farming for increased land and labour productivity in semi-arid West Africa. A review
}

\author{
Jens B. Aune ${ }^{1}$ (D) - Adama Coulibaly ${ }^{2}$ Ken E. Giller ${ }^{3}$
}

Accepted: 18 April 2017 / Published online: 15 May 2017

(C) INRA and Springer-Verlag France 2017

\begin{abstract}
Farmers in the semi-arid regions of West Africa face challenges related to poor crop establishment, variable rainfall, low soil fertility and a shortage of labour at times of peak demand. Farmers are generally low on resources. Given these conditions, it is important to develop farming practices that make efficient use of the available resources and reduce risks. Here, we review agricultural intensification in semi-arid West Africa using the principles of precision farming to assess the possibilities they offer. The basic idea is to create a favourable micro-environment in the planting pocket and to ensure timely sowing and weeding. In the context of precision farming in the semi-arid West Africa, this means (1) large seeds are selected, primed and treated with a mix of pesticides/fungicides. Seed priming increases yields in the order of 20 to $30 \%$, while seed treatment increases yields by $15 \%$. (2) Mineral fertilizers are applied; at doses as low as $0.3 \mathrm{~g}$ of fertilizer per pocket, they have been found to increase yields by half or more. (3) Seeds and fertilizers are distributed accurately by means of a combined planter-weeder, which can be motorized. (4) Mechanized sowing and weeding enable timely farm operations and reduce the workload. (5) Water loss is prevented by using zaï and stone bunds on soils with high run-off rates. (6) Care is taken to make use of farm resources in a targeted and efficient way. This can imply adjusting
\end{abstract}

Jens B. Aune

jens.aune@nmbu.no

1 Department of International Environment and Development Studies (Noragric), Norwegian University of Life Sciences,

1432 Aas, Norway

2 Institut d'Economie Rurale, Bamako, Mali

3 Plant Production Systems, Wageningen University, PO Box 430, 6700 AK Wageningen, The Netherlands micro-doses of manure and fertilizer to crops (sorghum needs less than millet) and soil types, sequenced sowing of crops according to their vulnerability to delayed sowing and applying organic input to soils. This paper is the first to review agricultural intensification in semi-arid West Africa within the context of precision farming. It shows how a low-cost package for precision farming can be developed, which can help to increase land and labour productivity, and works with all the major field crops in the region.

Keywords Agricultural intensification · Micro-dosing $\cdot$ Seed management $\cdot$ Pearl millet $\cdot$ Sorghum $\cdot$ Groundnut .

Mechanization

\section{Contents}

1. Introduction

2. Principles of precision agriculture in semi-arid West Africa

2.1 Seed treatment

2.2 Micro-dosing of mineral fertilizer

2.3 Mechanized sowing, fertilizer application and weeding

2.4 Tillage and water harvesting methods

2.5 Organic inputs

2.6 Location- and time-dependent management of farm resources

3. Broader implications of precision agriculture

4. Conclusions

References

\section{Introduction}

Farming in the semi-arid West Africa takes place under harsh agro-ecological conditions: low and unpredictable rainfall, high temperatures, high climatic variability, low soil fertility, 
attacks of pests and diseases and weed infestation. In addition, farmers face capital, labour and land constraints (Osbahr and Allan 2003). Public services are also weak, limiting farmers' access to specialized knowledge, infrastructure and credit. Markets are unpredictable, making it difficult for farmers to plan their activities in a rational way.

It is estimated that 30 million people face food insecurity in semi-arid West African countries in 2017, and 4.7 million children under are acutely malnourished (OCHA 2016). The poverty rate in these countries is above the average for subSaharan Africa as a whole. Self-sufficiency with regard to cereals is currently about $80 \%$ in the drylands of West Africa; it has been predicted to be below $40 \%$ in 2050 on the basis of an extrapolation of yield trends (van Ittersum et al. 2016). A recent study on food demand confirms the need for a rapid increase in food production in the West African dryland countries (Zhou and Staatz 2016). Therefore, it is important to develop farming practices that increase yields, make efficient use of resources and reduce farmers' risks. Precision farming as we describe fits well within the paradigm of "sustainable intensification", an approach which focuses on producing more food with less environmental impact (The Montpellier Panel Report 2014). It can furthermore be considered as a form of "Climate Smart Agriculture" (FAO 2017) as precision farming can increase yields, adapt agriculture to climate change and reduce GHG emissions from farming through more efficient use of inputs.

In this paper, the term "semi-arid West Africa" refers to the Sahelian zone, receiving 250 to $500 \mathrm{~mm}$ of annual rainfall, and to the Sahelo-Sudanian zone, receiving 500-900 mm (FAO 2006). Results from Sudan are included, as the agroecological conditions in this country are similar to those of semi-arid West Africa.

Precision farming offers options to address the problems faced by farmers in these regions. It promises a more efficient use of resources, a higher profitability, a reduction of environmental pressures and a better work environment. The key principle of precision agriculture is to ensure that the right treatment is applied at the right place at the right time (Gebbers and Adamchuk 2010). Optimalization is achieved by taking into account weather forecasts, soil properties, soil water content, threats posed by pests and weeds and the effects of crop rotation. Better yield predictions allow for more rational investment strategies.

In Europe and North America, advanced information systems, taking their data from satellites or drones, are used to determine the proper site-specific treatment (Gebbers and Adamchuk 2010; Tiwari and Jaga 2012). In low-income countries, precision agriculture mainly depends on farmers' observations and experiences (Mondal and Basu 2009). The most sophisticated technologies cannot be used here, because they are too costly, and often not even available. A more simplified version of precision farming is therefore presented in this paper focusing on dryland smallholder farmers in WestAfrica, but the principles are the same.

Precision farming allows for timely farming operations (sowing, application of pesticides, weeding and harvesting), the use of fertilizers and irrigation according to soil properties and rainfall and targeted crop protection measures (Bouma et al. 1999; Tiwari and Jaga 2012). Farmers in semi-arid West Africa already use elements of precision farming, such as planting the crops with the highest yields on the best land and applying mulch on degraded land (Lamers et al. 1998; Osbahr and Allan 2003). Here, we highlight the potential precision farming holds for improving agricultural productivity in semi-arid West Africa. There is no lack of knowledge of the agro-ecological constraints affecting agriculture in semi-arid West Africa, and technologies that help deal with these constraints have been developed. Such technologies include improved varieties, techniques for seed priming, the micro-dosing of fertilizers, targeted application of manure and mulch and knowledge of the advantages of cultivating food crops in combination with trees and fodder (Schlecht et al. 2006; Aune and Bationo 2008). As of yet, the adoption of improved agronomic practices has been slow. Obviously, it is important to develop technologies that are geared to the farmers' needs and constraints. Technologies such as mulching and tree planting are particularly difficult to implement, due to the widespread custom of allowing animals to graze freely after the harvest.

The way crops are grown in the semi-arid West African zone makes precision agriculture a feasible option. Sorghum and pearl millet, the major crops, are planted at low density varying from 5,000 planting pockets per hectare under marginal Sahelian conditions to 25,000 planting pockets per hectare in the more favourable Sudanian zone (Memento de l'Agronome 2009). Such sparse planting makes it feasible for organic manures and fertilizers to be applied to the planting pockets, creating a favourable micro-environment in the vicinity of the plant (see Fig. 1). This ensures rapid and uniform crop establishment, and reduces the need for re-sowing. By concentrating these substances in the vicinity of the plant, rather than spreading them thinly across the entire field, the best use is made of scarce resources. Precision farming in semi-arid regions should not only increase yields and farm income; it should also make agriculture less vulnerable to risks and reduce the labour burden.

We surveyed the literature to assess how the principles of precision farming can be fruitfully applied to crop and soil management in semi-arid West Africa. We are convinced that a substantial improvement in land and labour productivity can be realized by intelligently combining several techniques. 
Fig. 1 The concentration principle in precision farming in semi-arid West Africa

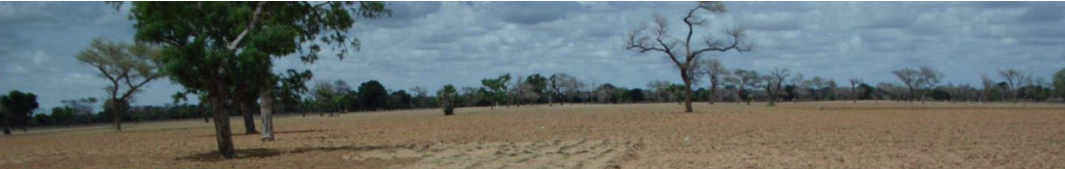

The concentration principle insemi-arid West Africa farming

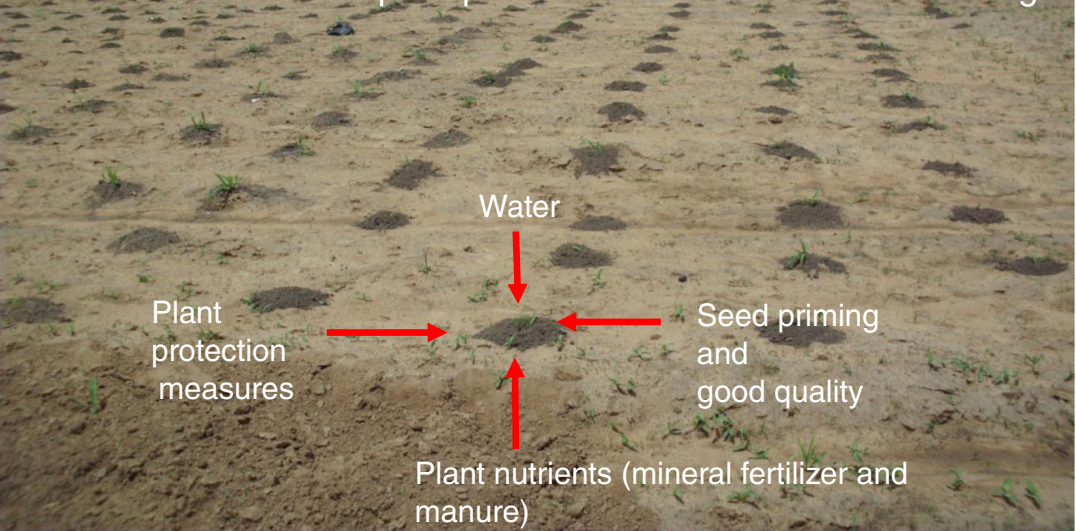

\section{Principles of precision farming in semi-arid West Africa}

Here, we discuss the principles of precision farming related to seed treatment, micro-dosing, management of organic material, water harvesting and use of weather forecasts.

\subsection{Seed treatment}

Good seed quality is fundamental to rapid and uniform crop establishment. Seed priming has been shown to be effective in improving early crop establishment in Mali and Sudan as well as in other tropical environments (Harris 2006). Seed priming has been found to be particularly useful under harsh conditions as in the Sahel (Aune et al. 2012). Soaking the seeds of pearl millet and sorghum for $8 \mathrm{~h}$ in water prior to sowing can shorten the germination time by 1 to 2 days and ensure a more uniform plant establishment. Seed priming can be used with all the major crops grown in semi-arid West Africa. In Sudan, seed priming increased yields by $107 \mathrm{~kg} \mathrm{ha}^{-1}$ (32\%) for sorghum, $71 \mathrm{~kg} \mathrm{ha}^{-1}$ (30\%) for pearl millet, $135 \mathrm{~kg} \mathrm{ha}^{-1}(18 \%)$ for groundnut and $86 \mathrm{~kg} \mathrm{ha}^{-1}$ (26\%) for cowpea (Aune and Ousman 2011; Ousman and Aune 2011). On-farm testing in Mali showed that seed priming increased yields by $159 \mathrm{~kg} \mathrm{ha}^{-1}$ (19\%) for sorghum and $99 \mathrm{~kg} \mathrm{ha}^{-1}$ (30\%) for pearl millet. Seed priming can therefore typically increase yields by 20 to $30 \%$ for all the major crops.

Seed priming can be started as soon as the soil is moist enough for the crops to be sown. If it rains in the evening, it is possible to prime the seeds overnight and sow them the following morning. The seeds should be surface-dried for about 1 to $2 \mathrm{~h}$ after completing seed priming to reduce stickiness (which makes sowing difficult).
The crops of the semi-arid West Africa are attacked by many pests and diseases. Primed seeds can be treated with a combined insecticide-fungicide after priming to ensure protection during the early stages of development. Seed treatment is less costly than applying plant protection agents to the whole field later and less likely to have non-target effects. Over 21 test sites in Mali treating seeds with a combined insecticidefungicide (Apron Star or Caïman Rouge) increased the average yield of sorghum and pearl millet by $167 \mathrm{~kg} \mathrm{ha}^{-1}(15 \%)$ (Aune et al. 2012).

Seed size has also been found to be an important factor in crop establishment. Large pearl millet seeds had faster establishment, increased shoot dry weight and developed more secondary roots than medium-sized and small seeds (Klaij and Hoogmoed 1993). A laboratory experiment with pearl millet and sorghum also showed that larger and higher-density seeds had faster seedling development (Mortlock and Vanderlip 1989). By selecting large seeds, crop establishment can be significantly improved.

\subsection{Micro-dosing of mineral fertilizer}

Nitrogen and phosphorus deficiencies are prevalent in the soils of semi-arid West Africa (Schlecht et al. 2006). In the drier northern areas of the Sahelo-Sudanian, lack of soil available phosphorus is especially a problem (Buerkert et al. 2001). Recommended doses of mineral fertilizers were calculated on the basis of tests in which broadcasting was applied. Since the 1990s, micro-dosing - applying a small rate of fertilizer within the planting pocket or in its close vicinity - has been intensively investigated (Buerkert et al. 2001). There are various ways of practicing micro-dosing. One method developed by ICRISAT in the 1990s consists of applying $2 \mathrm{~g}$ of diammonium phosphate (DAP) or $6 \mathrm{~g}$ of NPK per planting 
pocket (ICRISAT 2009). A lower-cost micro-dosing method has been developed in Mali and Sudan using as little as $0.3 \mathrm{~g}$ of fertilizer per pocket (Aune et al. 2007; Aune and Ousman 2011). The optimum amount of fertilizer is strongly dependent on the planting density (Table 1 ). The ICRISAT recommendation to use $2 \mathrm{~g}$ of DAP per pocket or $6 \mathrm{~g}$ of NPK per pocket (giving a similar amount of phosphorus as $2 \mathrm{~g}$ of DAP) will result in a rather high fertilizer dose particularly when there are 25,000 pockets per hectare as in central Mali (ICRISAT 2009). This corresponds to $50 \mathrm{~kg} \mathrm{ha}^{-1}$ of fertilizer when DAP is used or $150 \mathrm{~kg} \mathrm{ha}^{-1}$ when NPK is applied.

Table 2 summarizes the response to fertilizer micro-dosing of sorghum and pearl millet in locations from Sudan to Mali. In experimental settings, micro-dosing increased yields from 122 to $575 \mathrm{~kg} \mathrm{ha}^{-1}$, corresponding to a yield increase from 23 to $110 \%$. It appears that the application of 2 to $6 \mathrm{~g}$ of fertilizer per pocket gives a higher yield increase than the application of $0.3 \mathrm{~g}$ of fertilizer per pocket. However, in five out of eight of the studies with fertilizer rates from 2 to $6 \mathrm{~g}$ of fertilizer per pocket, the agronomic fertilizer use efficiency was below $7 \mathrm{~kg}$ grain per $\mathrm{kg}$ fertilizer. When $0.3 \mathrm{~g}$ of fertilizer is applied per pocket, the agronomic efficiency is generally good (above $10 \mathrm{~kg}$ grain per $\mathrm{kg}$ fertilizer). This means that farmers face a larger risk when using higher rates of micro-dosing.

In terms of the value-cost-ratio (VCR), the use of $0.3 \mathrm{~g}$ of fertilizer per pocket is more efficient than the use of 2 to $6 \mathrm{~g}$ of fertilizer per pocket. In Mali, the VCR ranged from 3.4 to 11.9 with $0.3 \mathrm{~g}$ per pocket, whereas the VCR ranged from 0.43 to 1.17 with $6 \mathrm{~g}$ per pocket. The economic viability of microdosing with $2 \mathrm{~g}$ of DAP per planting pocket has recently been put in doubt by Bielders and Gerard (2015). They found that $36 \%$ of 279 demonstration plots had a VCR less than 1 (negative return). Even where control plots had a relatively good yield (more than $400 \mathrm{~kg} \mathrm{ha}^{-1}$ ), 55\% of the experimental plots had a VCR below 1 . They suggested that micro-dosing with reduced rates may offer better results. They also found that the response to micro-dosing was stronger when crops were sown later in the season.

The effect of micro-dosing is also dependent on rainfall. Micro-dosing increased yields of sorghum by $330 \mathrm{~kg} \mathrm{ha}^{-1}$ in the Sahelian zone (400-600 $\mathrm{mm}$ of rainfall) and by $491 \mathrm{~kg} \mathrm{ha}^{-1}$ in the Sahelo-Sudanian zone $(600-1000 \mathrm{~mm}$ of

Table 1 Effects of fertilizer rate per pocket and pockets per hectare on application rate of fertilizer in $\mathrm{kg}$ per ha

\begin{tabular}{lccc}
\hline & \multicolumn{3}{l}{ Pockets per hectare } \\
\cline { 2 - 4 } & 5000 & 10,000 & 25,000 \\
\hline 0.3 g fertilizer per pocket & 1.5 & 3 & 7.5 \\
2 g fertilizer per pocket & 15 & 20 & 60 \\
6 g fertilizer per pocket & 30 & 60 & 150 \\
\hline
\end{tabular}

rainfall) (Tabo et al. 2006). It therefore appears that microdosing can be used more efficiently in the wetter areas of semi-arid West Africa.

Sorghum appears to respond better to micro-dosing than pearl millet. In the North Kordofan State of Sudan, $0.3 \mathrm{~g}$ of fertilizer per pocket increased pearl millet yields by $33 \%$ and sorghum yields by 50\% (Aune and Ousman 2011). Sorghum also appears to respond to larger doses than pearl millet. With sorghum, rates up to $0.9 \mathrm{~g}$ of fertilizer per pocket increased yields, while with pearl millet there was no yield increase beyond $0.3 \mathrm{~g}$ of fertilizer per pocket.

Investments in seed priming combined with micro-dosing are more profitable and less risky than investments in microdosing alone (Aune et al. 2012; Aune and Ousman 2011). Without seed priming, micro-dosing rates (of 0.3, 0.6 and $0.9 \mathrm{~g}$ per pocket) increased yields above a control by $24 \%$, whereas the yield increase was $132 \%$ with primed seeds (Aune and Ousman 2011). With pearl millet, the yield increase was 18 and 55\% for unprimed and primed seeds, respectively.

An advantage of the application of low doses of fertilizer is that it reduces labour pressure. When small quantities like $0.3 \mathrm{~g}$ of fertilizer per pocket are used, it is possible to mix the fertilizer and seed together in a 1:1 ratio and put the mixture into the soil in one go. An additional advantage is that it is possible to do this using a mechanized planter. When applying larger fertilizer rates, it is necessary to apply seeds and fertilizer in separate operations or to use planters that have separate hoppers for seeds and fertilizer.

A question with regard to micro-dosing is which type of fertilizer is best. When larger micro-dosing rates are used (more than $2 \mathrm{~g}$ per pocket), it is advisable to use DAP, as the price per kilogram of phosphorus is higher with NPK fertilizers (Bielders and Gerard 2015). However, when seed and fertilizer are mixed, it is recommendable to use NPK, in order to reduce the risk of burning the seeds (Aune et al. 2007).

\subsection{Mechanized sowing, fertilizer application and weeding}

Both manual and mechanized sowing are practiced in semiarid West Africa. Planters pulled by draught animals are available, and simple motorized planters have been developed by the Institut d'Economie Rurale (IER) in Mali. In 2016, an animal-drawn planter cost only 110 euro, while a motorized planter cost about 800 euro. When sowing small grains such as sorghum and millet, farmers typically take a pinch, using the thumb and the index finger, applying on average 11 sorghum or 35 millet seeds per pocket (Coulibaly 2010). Manual sowing results in a high variation in the number of seeds applied per pocket. Mechanical planters deliver a more uniform planting density, planting depth and number of seeds per pocket. At a planting density of 25,000 pockets per hectare, mechanized planting can be done in one fifth of the time required for manual sowing (Coulibaly et al. 2010). To plant 
Table 2 Response of pearl millet and sorghum to different rates of micro-dosing of single super phosphate (SSP), NPK (15-15-15 or 17-17-17) and diammonium phosphate (DAP)

\begin{tabular}{|c|c|c|c|c|c|c|}
\hline Fertilizer in $\mathrm{g}$ per pocket and $\mathrm{kg} / \mathrm{ha}$ & Country & Crop & $\begin{array}{l}\text { Yield increase } \\
\text { in } \mathrm{kg} / \mathrm{ha}\end{array}$ & $\begin{array}{l}\text { Yield increase } \\
\text { in } \%\end{array}$ & $\begin{array}{l}\text { Agronomic } \\
\text { efficiency }\end{array}$ & Source \\
\hline $1.3 \mathrm{~g} \mathrm{SSP}, 13 \mathrm{~kg} \mathrm{SSP} / \mathrm{ha}$ & Niger & Millet & 380 & 64.8 & 29.2 & Muehlig-Versen et al. 2003. \\
\hline $0.3 \mathrm{~g}, 5 \mathrm{~kg} \mathrm{NPK} / \mathrm{ha}$ & Mali & Millet & 122 & 55.7 & 24.4 & Aune et al. 2007 \\
\hline $4 \mathrm{~g} \mathrm{NPK}, 80 \mathrm{~kg} \mathrm{NPK} / \mathrm{ha}$ & Mali & Millet & 491 & 79.4 & 6.1 & Tabo et al. 2006 \\
\hline 2 g DAP, $20 \mathrm{~kg} \mathrm{DAP} / \mathrm{ha}$ & Niger & Millet & 230 & 61.4 & 11.5 & Tabo et al. 2006 \\
\hline $6 \mathrm{~g} \mathrm{NPK}, 60 \mathrm{~kg} \mathrm{NPK} / \mathrm{ha}$ & Niger & Millet & 394 & 90.3 & 6.6 & Hayashi et al. 2008 \\
\hline $0.3 \mathrm{NPK}, 10 \mathrm{~kg} \mathrm{NPK} / \mathrm{ha}$ & Sudan & Millet & 104 & 31.3 & 10.4 & Aune and Ousman 2011 \\
\hline $2 \mathrm{~g}$ DAP, $20 \mathrm{~kg} \mathrm{DAP} / \mathrm{ha}$ & Niger & Millet & 69 & 28.7 & 3.5 & Bielders and Gerard 2015 \\
\hline 2 g DAP, $20 \mathrm{~kg} \mathrm{DAP} / \mathrm{ha}$ & Niger & Millet & 329 & 40.0 & 16.5 & Ibrahim et al. 2015a \\
\hline $2 \mathrm{~g} \mathrm{DAP}, 20 \mathrm{~kg} \mathrm{DAP} / \mathrm{ha}$ & Niger & Millet & 548 & 107.5 & 27.4 & Ibrahim et al. $2015 b$ \\
\hline $0.3 \mathrm{~g}$ DAP or NPK, $7.5 \mathrm{~kg}$ DAP or NPK $/ \mathrm{ha}$ & Mali & Sorghum & 281 & 40.9 & 37.5 & Aune et al. 2007 \\
\hline $0.6 \mathrm{~g} \mathrm{NPK} .25 \mathrm{~kg} \mathrm{NPK} / \mathrm{ha}$ & Sudan & Sorghum & 282 & 68.7 & 11.3 & Aune and Ousman 2011 \\
\hline $4 \mathrm{~g} \mathrm{NPK}, 125 \mathrm{~kg} / \mathrm{ha}$ & Burkina Faso & Sorghum & 317 & 63.1 & 2.5 & Tabo et al. 2006 \\
\hline $4 \mathrm{~g} \mathrm{NPK}, 120 \mathrm{~kg} / \mathrm{ha}$ & Mali & Sorghum & 567 & 83.0 & 4.7 & Tabo et al. 2006 \\
\hline
\end{tabular}

by hand, an average-sized farm of 4 ha in the Sahelo-Sudanian zone of Mali takes 48 man-days with this planting density. Mechanical planters also make it possible to time the sowing more accurately.

As we have seen, if fertilizer rates in the order of $0.3 \mathrm{~g}$ per pocket are used, seeds and fertilizer can be mixed together in the hopper of the planter, allowing for the simultaneous application of seed and fertilizer. This does not harm the seeds if small doses of fertilizer are used (if higher-rate adaptations of the planter are required). In mechanized sowing, no manual handling of the seed treated with plant-protection agents is needed.

Planters can also be used for weeding if fitted with tines. Weeds are commonly removed manually, but this is a laborious process leading to delays. Within the rows, manual weeding is still needed, even when mechanized weeding is used to remove the weeds between rows. The parasitic weed striga (Striga hermonthica) is a serious problem in semi-arid West Africa, particularly in areas with infertile soils. The use of fertilizer micro-dosing helps to reduce the problem with striga infestation as it appears that a fertilized crop outgrows the striga (Aune et al. 2007).

\subsection{Tillage and water harvesting methods}

Tillage has been shown to increase yields by creating a rough seedbed that can protect the seedling, reducing bulk density and crust formation, and promoting root development (Klaij and Hoogmoed 1993). The benefits of tillage are generally more pronounced in heavier-textured soils (Pingali et al. 1987).
Water harvesting is particularly important when dealing with soils prone to crust formation. Zaï can be of use here. A zaï is a planting basin (pit) with a diameter of 20 to $40 \mathrm{~cm}$ and a depth of 10 to $20 \mathrm{~cm}$ (Roose et al. 1999). Manure and compost are often put inside the zaii, in order to create a water- and nutrient-rich micro-environment. The zaï was originally developed in the Yatenga region of Burkina Faso, and was later introduced to Mali and Niger. On a degraded alfisol in the Yatenga region in Burkina Faso, the zaï basin alone increased yield of sorghum compared with flat planting by $90 \mathrm{~kg} \mathrm{ha}^{-1}$ over 2 years. Zaï with $3 \mathrm{t}$ of manure per hectare gave an increase of $474 \mathrm{~kg} \mathrm{ha}^{-1}$ and zaï with NPK $\left(10 \mathrm{~kg} \mathrm{~N} \mathrm{ha}^{-1}\right.$ and $20 \mathrm{~kg} \mathrm{Pha}^{-1}$ ) an increase of $619 \mathrm{~kg} \mathrm{ha}^{-1}$ (Roose et al. 2008). So it is not enough just to dig the zaii; nutrients are needed in the form of organic manures or mineral fertilizers (Fatondji et al. 2006; Sawadogo et al. 2008). The digging of zaï is a laborious process, taking about $300 \mathrm{~h}$ per hectare (Roose et al. 2008). This, together with the limited availability of manure, is a constraint on its adoption (Wildemeersch et al. 2013). Other waterharvesting structures such as stone bunds and tied ridges can be used to reduce run-off and to concentrate water in the vicinity of the plant. Tied ridging is particularly effective on loamy soils (Kouyaté et al. 2000).

\subsection{Organic inputs}

In order to ensure the long-term sustainability of agriculture in semi-arid West Africa, it is imperative that as much organic matter as possible be recycled. This helps to maintain and improve the chemical, physical and biological properties of soils (Buerkert et al. 2000). The major organic inputs are farmyard manure, compost, crop residues and mulch from 
trees or decaying roots from previous crops. Under the current free grazing system, most of the carbon inputs to the soil come from farmyard manure, compost and decaying roots. The use of manure is compatible with mechanization. Crop residues are very suitable for soil amendment, but because of their high value as fodder, farmers are reluctant to put them to this use. The value of crop residues depends on the milk and meat price, the availability of farmyard manure, their role in feeding traction animals and in ensuring the survival of animals (Turmel et al. 2015).

The quantity of manure is limited, and its quality is highly variable (Harris 2002). Recommended application rates are in the order of 3 to $5 \mathrm{tha}^{-1}$ (Harris 2002). The effects of manure application can last several years (Schlecht and Hiernaux 2004; Bielders and Gerard 2015). Manure is either applied directly by animals grazing on crop residues or collected from the kraal and transported to the field. Improved manure management can be part of an intensification process set off by population pressure or the loss of grazing land (Harris 2002). An important issue in precision farming is how to increase the quantity and the quality of manure and how to make use of it in the most efficient way. More manure can be made available through a better integration of crop and livestock production, improved fodder production and improved collection methods (Harris 2002). The quality of the manure can be increased by improving the fodder quality, by using bedding material under the animals to capture more of the urine and by protecting the kraal from wind and rain (Nzuma and Murwira 2000; Rufino et al. 2007; Tittonell et al. 2010).

Since manure is a valuable and limited resource, it is advantageous to apply it by micro-dosing. When testing the rates of 1,2 and $3 \mathrm{t} \mathrm{ha}^{-1}$ of manure by broadcasting or microdosing, it was found that pocket placement of manure gave $88 \mathrm{~kg} \mathrm{ha}^{-1}$ more yield than broadcasting (Ibrahim et al. 2015). Pocket-placed manure stimulated root development. The best treatment was found to be $2 \mathrm{tha}^{-1}$ of manure applied as $200 \mathrm{~g}$ per pocket in combination with $20 \mathrm{~kg}$ DAP ha ${ }^{-1}$ (placed in pockets).

Although it is difficult to practice mulching with crop residues in semi-arid West Africa, it can contribute to improved soil quality and, with that, to larger yields (Buerkert et al. 2000). Using crop residues as mulch $\left(2 \mathrm{t} \mathrm{ha}^{-1}\right)$ increased yields by more than $60 \%$ (Rebafka et al. 1994). The use of crop residues as mulch can become more realistic if crop yields are increased (Valbuena et al. 2015), if alterative fodder sources are developed or if motorized traction replaces traction animals (Baudron et al. 2015).

In semi-arid West Africa, crops are typically grown in parklands with scattered trees. These trees provide multiple economic and ecological benefits. Economically important trees include Adansonia digitata, Faidherbia albida, Vitellaria paradoxa and Parkia biglobosa (Bayala et al. 2015). The effect of the presence of trees on crops like pearl millet is well-established. In Niger, it was found that the millet yield under the canopy of $F$. albida was $36 \%$ greater than outside the canopy (Kho et al. 2001). Faidherbia albida has a reverse phenology: the tree drops its leaves at the beginning of the rainy season, limiting the shading effect. The integration of trees on farmland cannot be defined as precision farming, but it contributes to make precision farming more sustainable.

During the last 10 years, there has been an increasing interest in use of the indigenous shrubs Guiera senegalensis and Piliostigma reticulatum for mulching. These shrubs have deep roots, and therefore hardly compete with food crops for water. They have unpalatable leaves that are not eaten by grazing animals. The shrubs can be pruned at the start of the rainy season; their stems and twigs can be used as firewood. In Senegal, plots planted with $G$. senegalensis produced $212 \mathrm{~kg} \mathrm{ha}^{-1}$ more millet (Dossa et al. 2012) than plots without the shrub. The response to fertilizer also increased when the shrub was present. The disadvantage of shrub-based systems is that mechanization becomes difficult if there is a dense tree stand.

\subsection{Location- and time-dependent management of farm resources}

Studies on local practices of soil fertility management in Niger and Mali show that farmers apply manure to specific places and soil types, relying on their own knowledge of plant indicators (Osbahr and Allan 2003; Krings 1991). For example, farmers are aware that soils are more fertile in the vicinity of F. albida trees, termite mounds and old livestock pens. Farmers also take into account climatic conditions during the season. Research results now start to appear from the drylands of West Africa that can help farmers achieve a targeted management of farm resources. This means that informed decisions can be made about the order in which the crops are sown, the alternation of crops, the timing of the sowing of different crops and the application of fertilizer with regard to the condition and needs of specific fields and crops.

The sowing order is an important issue, as different crops have different optimal sowing times. When testing three different sowing times in southern Mali, it was found that grain yields of maize and sorghum were lower when sowing was delayed to July, while for millet the opposite was the case (Traoré et al. 2014). The first two plantings of sorghum produced on average an $88 \%$ higher yield than a later planting. Sorghum and maize suffer more from delayed sowing than millet, and therefore should be sown first. For all of these cereal crops, the stover yield was greater the earlier the sowing date.

Farmers normally do not have the financial resources to apply fertilizer to all of their crops. Sorghum and groundnut appear to respond better to micro-dosing than pearl millet and cowpea. In the North Kordofan state of Sudan, the largest 
VCRs for sorghum, groundnut, pearl millet and cowpea (attained with the help of micro-dosed fertilizer) were 11.9, 9.1, 6.6 and 1.8 respectively (Aune and Ousman 2011; Ousman and Aune 2011). In Mali, sorghum also responded better to micro-dosing than pearl millet (Aune et al. 2007).

The question on which soil type to apply fertilizer is also important with respect to resource allocation. Results from Niger indicate that if farmers do not have sufficient resources to apply mineral fertilizer on all of their fields, they can best be applied to fields with high productivity (often infields close to the homestead), and not to fields with poor productivity (Fofana et al. 2008; Lamers et al. 1998). The risk of nutrient mining will also be lower with micro-dosing in infields, because farmers apply most of the farmyard manure to such fields. Recovery of fertilizer phosphorus was almost twice as high on infields than on outfields. In Niger, farmers target farmyard manure to soils of poor fertility and soils with hardpans (Schlecht and Buerkert 2004). Studies in Niger and Burkina Faso showed that the risk of a negative return on micro-dosing decreased as the average yield increased (Buerkert et al. 2001). Bielders and Gerard (2015), on the other hand, found that the increase in grain yield was higher on plots where the control yield was below $400 \mathrm{~kg} \mathrm{ha}^{-1}$. The high-yielding control plots in this study were mostly manured plots, which may explain the weak response to micro-dosing. Manured plots can receive in the order of $10 \mathrm{t} \mathrm{ha}^{-1}$ manure, which is well above the requirements for plant nutrient supply (Bielders and Gerard 2015). We conclude that the return on micro-dosing is best on sites with relatively good fertility such as infields, except when they are well-manured; in that case, they do not benefit from micro-dosing.

The response to fertilizer may also depend on the crop rotation. In the cotton production area of southern Mali, intercrops of maize and cowpea performed better after maize or cotton to which fertilizer had been applied (Falconnier et al. 2016). Maize in intercrop with cowpea produced the same yield as the sole maize crop, with the cowpea providing an added benefit.

Making use of weather forecasting is an important element of precision farming in large-scale agriculture. Weather forecasts allow farmers to choose the right timing of farm operations, from deciding on a land contract to the selling of crops. Knowledge of weather conditions may also influence decisions on which crops and varieties to grow, on planting density and rates of organic and mineral fertilizer application and on crop protection measures (Hansen 2005). Seasonal weather forecasts are available in West Africa through PRESAO, the Climate Outlook Forum for West Africa. This forecast gives a probability estimate indicating whether the cumulative rainfall in the coming season is expected to be below, near or above the long-term norm. Decadal weather forecasts are provided by the European Centre for Mid-term Weather Forecasts (ECMWF). Weather forecasts can be provided to farmers by radio, by SMS and by extension agents. A simulation experiment gauging the response of Senegalese farmers to decadal and seasonal forecasts showed that decadal forecasts were most useful to them (Roudier et al. 2014). When farmers adjusted their activities to weather forecasts, yields increased in one third of the cases, while losses were observed in only a few cases. Farmers responded to the forecasts by changing the sowing dates, the crop varieties and the use of manure and mineral fertilizer. The importance of weather forecasts is expected to grow in the future.

The above management decisions can be grouped into strategic (long-term decisions), tactical (decisions covering a crop rotation period of 2 to 5 years) and operational decisions (dayto-day decisions) (Bouma et al. 1999). Decisions at all three levels are relevant for precision farming in semi-arid West Africa (Table 3). Examples of strategic decisions include choices relating to the cropping system, the grazing management, the degree of mechanization and the source of traction power. Decisions at the tactical level include choices relating to crop rotation, the intercropping system and pest and weed management. Among operational-level decisions are those concerning the timing of farm operations and the rates and types of input depending on the development of the season. The decisions taken at the strategic level and tactical level dictate what kind of management decisions are possible at the operation level. For example, farm operations can be timed more adequately if farmers have access to traction power and mechanization.

\section{Broader implications of precision agriculture}

The technologies applied in precision agriculture, such as seed priming, seed treatment, micro-dosing, manuring and water harvesting, provide cost-efficient methods to increase yields in semi-arid West Africa. They help to increase yields by ensuring a more uniform crop establishment and promoting root development. When assessing the sustainability of these methods, it is important to consider their environmental, economic and social dimensions. Micro-dosing has been questioned on the grounds that it can lead to nutrient mining (Camara et al. 2013). However, we should not be focusing on the nutrient balance alone, but consider the broader impact of micro-dosing in the farming system as the sustainability of a technology also depends on the profitability, affordability and feasibility for the farmers. Micro-dosing can be considered as an entry point for agricultural intensification. For the farmers, it makes most sense to use the fertilizer rates with the best return to their investment. Measured against this yardstick, a fertilizer rate of $0.3 \mathrm{~g}$ per pocket is clearly superior to a rate of $6 \mathrm{~g}$ per pocket (Aune et al. 2007). However, over time there will be a need for increased fertilizer rates. When farmers in other parts of the world have started to use fertilizers, they 
Table 3 Technological choices grouped according to strategic, tactical and operational management
Technological choices

\begin{tabular}{cc}
$\begin{array}{c}\text { Strategic } \\
\text { management }\end{array}$ & $\begin{array}{c}\text { Cropping system (annual or perennial system), livestock system (free grazing or stall } \\
\text { feeding), mechanization level, source of traction power, integration of trees in farming } \\
\text { system, management of crop residues and farm yard manure and harvest and } \\
\text { post-harvesting methods }\end{array}$ \\
$\begin{array}{c}\text { Tactical } \\
\text { management }\end{array}$ & $\begin{array}{c}\text { Crop choice, input use, crop rotation and intercropping, pest and weed management } \\
\text { Operational } \\
\text { management }\end{array}$ \\
\hline
\end{tabular}

used fertilizer rates that were affordable and profitable. A recent evaluation report of micro-dosing and seed priming in Mali shows that yields increased from 50 to $100 \%$ in farmers' fields (Djiga 2015). In this way, farmers created a production surplus that enabled them to buy more animals and donkey carts. This in turn increased the amount of manure, and made the manure easier to transport. Food security improved and a positive spiral was set in motion, leading to more production and increasing food security. We argue that the long-term sustainability of a practice depends on its ability to create a surplus, which can outweigh short-term problems such as a negative nutrient balance.

Integration of grain legumes into the cropping system either as an intercrop or in rotation has been advocated. They increase farmers' incomes, and provide fodder and inputs by the fixation of gaseous nitrogen. However, farmers continue to plant grain legumes sparsely (Schlecht et al. 2006). The cultivation of grain legumes is often labour-demanding. When planting groundnuts with a row spacing of $40 \mathrm{~cm}$, there is $25 \mathrm{~km}$ of row per hectare. Manual sowing of groundnut is therefore often delayed. Increasing mechanization will facilitate the expansion of the cultivation of groundnuts and other grain legumes, and thereby contribute to a more positive nutrient balance.

\section{Conclusion}

Precision farming in semi-arid West Africa focuses on selecting and treating seeds to allow for fast and secure crop establishment and on creating a micro-environment offering favourable growing conditions for the sown seeds. We have described the different techniques involved, from the selection of large seeds, via seed priming and seed treatment with a combined fungicide-insecticide, to the application of microdoses of mineral fertilizer and manure. Ideally, these methods should be combined with mechanized sowing and weeding in order to enable timelier farm operations and more uniformity in the spacing of plants, sowing depth and the number of seeds per pocket. Precision farming can become even more effective if attention is paid to the resources available to the farmer, soil variability and the ability of different crops to make efficient use of improved soil conditions. Crop yields and the return on farmers' investments can be improved by better farm management and by rationally determining the sequence in which the crops are sown, the position of different crops within a rotation cycle, the choice of land type (infields or outfields) for specific crops and the targeted micro-dosing of manure and fertilizers. When applying these techniques together, a substantial agricultural intensification can be realized, with greater land and labour productivity and greater efficiency. Despite the research advances on technologies relevant for precision farming in West Africa, the need remains for research on how to efficiently allocate farm resources in time and space and how best to combine technologies that are both yield enhancing and labour saving.

Precision farming can be considered as a starting point for a sustainable intensification in semi-arid West Africa. Different technologies can be combined in a "starter-pack", such as intercropping with grain legumes, top-dressing of fertilizer, additional manure application, mulching and agro-forestry, and the package can be adapted to the opportunities and resources of individual farmers. Agricultural research in Africa has for too long focused on yield-enhancing technologies. Farming is often associated with drudgery; a focus on labour-saving technologies may increase the attractiveness of a career in agriculture for the next generations $\mathrm{ha}_{-1}$.

\section{References}

Aune JB, Bationo A (2008) Agricultural intensification in the Sahel- the ladder approach. Agric Syst 98:119-125. doi:10.1016/j.agsy.2008. 05.002

Aune JB, Ousman A (2011) Effect of seed priming and micro-dosing of fertilizers on sorghum and pearl millet in Western Sudan. Exp Agr 47:419-435. doi:10.1017/S0014479711000056

Aune JB, Doumbia M, Berthe A (2007) Microfertilizing sorghum and pearl millet in Mali. Agronomic, economic and social feasibility. Outlook Agr 36:199-203. doi:10.5367/000000007781891504

Aune JB, Traoré CO, Mamadou S (2012) Low-cost technologies for improved productivity of dryland farming in Mali. Outlook Agr 41:103-108. doi:10.5367/oa.2012.0084 
Baudron F, Sims B, Justice S, Kahan DG, Rose R, Mkomwa S, Kaumbutho P, Sariah J, Nazare R, Moges G, Gerard B (2015) Reexamining appropriate mechanization in Eastern and Southern Africa: two-wheel tractors, conservation agriculture, and private sector involvement. Food Sci 7:889-904. doi:10.1007/s12571-0150476-3

Bayala J, Sanou J, Teklhaimanot Z, Ouedraogo SJ, Kalinganire A, Coe R, van Noordwijk M (2015) Advances in knowledge of processes in soil-tree-crop interaction in parkland systems in the West African Sahel: a review. Agric Ecosyst Environ 205:25-35. doi:10.1016/j. agee.2015.02.018

Bielders CL, Gerard B (2015) Millet response to micro-dosing fertilization in south-western Niger: effect of antecedent fertility management and environmental factors. Field Crop Res 171:165-175. doi: 10.1016/j.fcr.2014.10.008

Bouma J, Stoorvogel J, van Alphen BJ, Booltink HWG (1999) Pedology, precision agriculture, and the changing paradigm of agricultural research. Soil Sci Soc Am J 63:1763-1768. doi:10.2136/sssaj1999. $6361763 x$

Buerkert A, Bationo A, Dossa K (2000) Mechanisms of residue mulchinduced cereal growth increases in West Africa. Soil Sci Soc Am J 64:346-358. doi:10.2136/sssaj2000.641346x

Buerkert A, Bationo A, Piepho HP (2001) Efficient phosphorus application strategies for increased crop production in sub-Saharan West Africa. Field Crop Res 72:1-15. doi:10.1016/S0378-4290(01) 00166-6

Camara BS, Camara F, Berthe A, Oswald A (2013) Micro-dosing of fertilizer-a technology for farmers' needs and resources. Int J Agri Science 3:387-399

Coulibaly A (2010) Amélioration de la productivité du mil et du sorgho par une gestion rationnelle de l'engrais en micro-doses en zones sahélienne et soudano-sahélienne du Mali-Thèse pour Diplôme de Doctorat de l'Université de Bamako, Mali, p 167

Coulibaly A, Aune JB, Sissoko P (2010) Etablissement des cultures vivrières dans les zones sahélienne et soudano sahélienne du Mali. Dryland Coordination Group Report no. 60, Oslo. http://drylandsgroup.org/assets/documents/Publications/1045-gcoza_rapport_no. 60.pdf. Accessed 21 September 2016

Djiga A (2015) Evaluation d'impact du projet d'établissement des cultures vivrières dans les zones zahéliennes et soudano-sahéliennes du Mali. Dryland Coordination Group, Oslo http://drylands-group.org/ assets/documents/Impact-Evaluation-Mali-FINAL.pdf. Accessed 21 September 2016

Dossa EL, Diedhiou I, Khouma M, Sene M, Lufafa A, Kizito F, Samba SAN, Badiane AN, Diedhiou S, Dick RP (2012) Crop productivity and nutrient dynamics in a shrub (Guiera senegalensis)-based farming system of the Sahel. Agron J 104:1255-1264. doi:10.2134/ agronj2011.0399

Falconnier G, Descheemaeker K, van Mourik T, Giller KE (2016) Unravelling the causes of variability in crop yields and treatment responses for better tailoring of options for sustainable intensification in southern Mali. Field Crop Res 187:113-126. doi:10.1016/j. fcr.2015.12.015

FAO 2006 Sahel weather and crop situation report. Report 3-08 August 2006. http://www.fao.org/docrep/009/j8124e/j8124e00.htm. Accessed 21 September 2016

FAO (2017) Climate-smart agriculture. FAO, Rome http://www.fao.org/ climate-smart-agriculture/overview/en/ (Assessed 24 February 2017)

Fatondji D, Martius C, Bielders CL, Vlek PLG, Bationo A, Gerard B (2006) Effects of planting technique on pearl millet yield, nutrient uptake, and water use on degraded land in Niger. Nutr Cycl Agroecosys 76:203-217. doi:10.1007/s10705-005-6209-9

Fofana B, Wopereis MCS, Bationo A, Breman H, Mando A (2008) Millet nutrient use efficiency as affected by natural soil fertility, mineral fertilizer use, and rainfall in the West African Sahel. Nutr Cycl Agroecosyst 81:25-36. doi:10.1007/s10705-007-9146-y

Gebbers R, Adamchuk VA (2010) Precision agriculture and food security. Science 327:828-830. doi:10.1126/science.1183899

Hansen JW (2005) Integrating seasonal climate prediction and agricultural models for insights into agricultural practice. Phil Trans R Soc B 360:2037-2047. doi:10.1098/rstb.2005.1747

Harris F (2002) Management of manure in farming systems in semi-arid West Africa. Exp Agr 38:131-148. doi:10.1017/S0014479702000212

Harris D (2006) Development and testing of "on-farm" seed priming. Adv Agron 90:129-178. doi:10.1016/S0065-2113(06)90004-2

Hayashi K, Abdoulaye T, Gerard B, Bationo A (2008) Evaluation of application timing in fertilizer micro-dosing technology on millet production in Niger West Africa. Nutr Cycl Agroecosyst 80:257265. doi:10.1007/s10705-007-9141-3

Ibrahim A, Abaidoo RC, Fadondji D, Opoku A (2015a) Integrated use of fertilizer micro-dosing and Acacia tumida mulching increases millet yield and water use efficiency in Sahelian semi-arid environment. Nutr Cycl Agroecosyst 103:375-388. doi:10.1007/s10705-0159752-Z

Ibrahim A, Pasternak D, Fatondji D (2015b) Impact of depth of placement of mineral fertilizer micro-dosing on growth, yield and partial nutrient balance in pearl millet cropping system in the Sahel. J Agr Sci-Cambridge 153:1412-1421. doi:10.1017/S0021859614001075

ICRISAT (2009) Fertilizer micro-dosing. Boosting production in unproductive lands. http://www.icrisat.org/impacts/impact-stories/icrisatis-fertilizer- micro-dosing.pdf. Accessed 21 September 2016

Kho RM, Yacouba B, Yayé M, Katkoré B, Moussa A, Iktam A, Mayaki A (2001) Separating the effects of trees on crops: the case of Faidherbia albida and millet in Niger. Agrofor Syst 52:219-238. doi:10.1023/A:1011820412140

Klaij MC, Hoogmoed WB (1993) Soil-management for crop production in African Sahel. II. Emergence, establishment and yield of pearl millet. Soil Till Res 25:301-355. doi:10.1016/0167-1987(93) 90029-O

Kouyaté Z, Franzluebbers K, Juo ASR, Hossner LR (2000) Tillage, crop residue, legume rotation, and green manure effects on sorghum and millet yields in the semi-arid tropics of Mali. Plant Soil 225:141151. doi:10.1023/A:1026589528352

Krings T (1991) Standortgerechte Elemente in den Landnutzungssystemen der Senoufo, Bwa, Dogon und Somono. Abhandlungen $(\mathrm{PhD})$. Instutut für Geographische Wissenschaften. Freie Universität Berlin, Dietrich Reimer Verlag, Sonderheft 3, Berlin

Lamers JM, Bruentrup N, Buerkert A (1998) The profitability of traditional and innovative mulching techniques using millet crop residues in the West African Sahel. Agric Ecosyst Environ 67:23-35. doi:10.1016/S0167-8809(97)00092-3

Memento de l'agronome (2009) CIRAD-GRET. Ministère des Affaires Etrangères, France, $\mathrm{p} 1691$

Mondal P, Basu M (2009) Adoption in precision agriculture technologies in India and some other developing countries. Scope, present status and strategies. Prog Nat Sci 19:659-666. doi:10.1016/j.pnsc.2008. 07.020

Mortlock MY, Vanderlip RL (1989) Germination and establishment of pearl millet and sorghum of different seed qualities under high temperature environments. Field Crop Res 22:195-209. doi:10.1016/ 0378-4290(89)90092-0

Muehlig-Versen B, Buerkert A, Bationo A, Roemheld V (2003) Phosphorus placement on acid arenosols of the west Africa Sahel. Expl Agric 39:307-325. doi:10.1017/S0014479703001261

Nzuma JK, Murwira HK (2000) Improving the management of manure in Zimbabwe. Managing Africa's Soils, No. 15. London: International Institute for Environment and Development. http://pubs.iied.org/ pdfs/X169IIED.pdf. Accessed 13 May 2016 
OCHA (2016) Sahel 2017: Overview of humanitarian needs and requirements. United Nations Office for the Coordination of Human Affairs. https://www.humanitarianresponse.info/system/files/ documents/files/hnro_sahel-2017-en_2.pdf. Accessed 6 February 2017

Osbahr H, Allan C (2003) Indigenous knowledge of soil fertility management in southwest Niger. Geoderma 111:457-479. doi:10.1016/ S0016-7061(02)00277-X

Ousman A, Aune JB (2011) Effect of seed priming and micro-dosing of fertilizer on groundnut, sesam and cowpea in Western Sudan. Exp Agr 47:431-443. doi:10.1017/S0014479711000068

Pingali P, Bigot Y, Binswanger HP (1987) Agricultural mechanization and the evaluation of farming systems in sub-Saharan Africa. The John Hopkins University Press, Baltimore

Rebafka FP, Hebel A, Bationo A, Stahr K, Marschner H (1994) Shortterm and long-term effects of crop residues and phosphorus fertilization on pearl-millet yield and on an acid soil in Niger, West-Africa. Field Crop Res 36:113-124. doi:10.1016/0378-4290(94)90060-4

Roose E, Kabore V, Guenat C (1999) Zaï practice: a West African traditional rehabilitation system for semi-arid degraded lands, a case study in Burkina Faso. Arid Soil Res Rehab 13:343-355. doi:10. 1080/089030699263230

Roudier P, Muller B, Aquino P, Roncoli C, Soumaré MA, Batté L, Sultan B (2014) The role of climate forecasts in smallholder agriculture: lessons from participatory research in two communities in Senegal. Climate Risk Manag 2:42-55. doi:10.1016/j.crm.2014.02.001

Rufino MC, Tittonell P, van Wijk MT, Castellanos-Navarrete A, Delve RJ, de Ridder N, Giller KE (2007) Manure as a key resource within smallholder farming systems: analysing farm-scale nutrient cycling efficiencies with the NUANCES framework. Livest Sci 112:273287. doi:10.1016/j.livsci.2007.09.011

Sawadogo H, Bock L, Lacroix D, Zombré NP (2008) Restauration des potentialités de sols dégradés à l'aide du zaï et du compost dans le Yatenga (Burkina Faso). Biotechnol Agron Soc Environ 12:279 $290 \mathrm{http}: / /$ popups.ulg.ac.be/1780-4507/index.php?id=2573

Schlecht E, Buerkert A (2004) Organic input and farmers' management strategies in millet fields of western Niger. Geoderma 121:271-289. doi:10.1016/j.geoderma.2003.11.015

Schlecht E, Hiernaux P (2004) Beyond adding up input and output: process assessment and upscaling in nutrient modeling flows. Nutr Cycl Agroecosys 70:303-319. doi:10.1016/j.geoderma.2003.11.015
Schlecht E, Buerkert A, Tielkes E, Bationo A (2006) A critical analysis of challenges and opportunities for soil fertility restoration in SudanoSahelian West Africa. Nutr Cycl Agroecosys 76:109-136. doi:10. 1007/s10705-005-1670-Z

Tabo R, Bationo A, Maimouna KD, Hassan O, Koala S (2006), Fertilizer micro-dosing for the prosperity of small-holders farmers in the Sahel: final report. Global Theme on Agroecosystems Report No. 23. PO. Box 12404, ICRISAT, Niamey, 28 p. http://ejournal.icrisat. org/mpii/v3i1/pdfs/24-2006.pdf. Accessed 21 September 2016

The Montpellier Panel Report (2014) Sustainable intensification: a new paradigm for African agriculture, London, http://goo.gl/ofRMNZ (Assessed 24 February 2017)

Tittonell P, Rufino MC, Janssen BH, Giller KE (2010) Carbon and nutrient losses during manure storage under traditional and improved practices in smallholder crop-livestock systems-evidence from Kenya. Plant Soil 328:253-269. doi:10.1007/s11104-009-0107-x

Tiwari A, Jaga PK (2012) Precision farming in India - a review. Outlook Agr 41:139-143. doi:10.5367/oa.2012.0082

Traoré B, van Wijk MT, Descheemaeker K, Corbels M, Rufino MC, Giller KE (2014) Evaluation of climate adaptation options for Sudano-Sahelian cropping systems. Field Crop Res 156:63-75. doi:10.1016/j.fcr.2013.10.014

Turmel M-S, Speratti A, Baudron F, Verhuls N, Govaerts B (2015) Crop residue management and soil health: a systems analysis. Agric Syst 134:6-16. doi:10.1016/j.agsy.2014.05.009

Valbuena D, Tui SH-K, Erenstein O, Teufel N, Duncan A, Abdoulaye T, Swain B, Mekonnen K, Germaine I, Gerard B (2015) Identifying determinants, pressures and trade-offs of crop residue use in mixed smallholder farms in Sub-Saharan Africa and South Asia. Agric Syst 134:107-118. doi:10.1016/j.agsy.2014.05.013

Van Ittersum MK et al (2016) Can Africa feed itself? PNAS 113:14964 14969. doi:10.1073/pnas. 1610359113

Wildemeersch JCJ, Timmerman E, Mazijn B, Sabiou M, Ibro G, Garba M, Cornelis W (2013) Assessing the constraints to adopt water and soil conservation techniques in Tillaberi, Niger. Land Degrad Dev 26:491-501. doi:10.1002/ldr.2252

Zhou Y, Staatz J (2016) Projected demand and supply for various foods in West Africa: implication for investments and food security. Food Policy 61:198-212. doi:10.1016/j.foodpol.2016.04.002 